The International Journal of Indian Psychology

ISSN 2348-5396 (e) | ISSN: 2349-3429 (p)

Volume 5, Issue 1, DIP: 18.01.103/20170501

DOI: $10.25215 / 0501.103$

http://www.ijip.in | October-December, 2017

Research Article

\title{
Constructivism and the Classroom Curriculum
}

\author{
Dr. Md. Mahmood Alam ${ }^{1} *$
}

\section{ABSTRACT}

Constructivism suggests that humans construct knowledge and meaning from their experiences. So an individual's knowledge is a function of one's prior experiences, mental structures, and beliefs that are used to interpret objects and events. The present study tries to seek for what constructivists believe regarding curriculum development; they claim that learners construct their own reality or at least interpret it based upon their perceptions of experiences, What someone knows is grounded in perception of the physical and social experiences which are comprehended by the mind (Jonasson, 1991). Feature of this approach is that it does not adopt doctrinaire allegiance to particular levels of teacher input ( as can be the case with teaching through discovery learning , or direct instruction) but rather the level of teacher guidance (a) is determined for particular learning activities by considering the learners and the materials to be learnt ; (b) shifts across sequences of teaching and learning episodes, and includes potential for highly structured guidance and, as well as more exploratory activities. When understood in these terms, constructivism provides a sound theoretical basis for informing teaching at all levels, and in all disciplines. If our efforts in reforming education for all students are to succeed, then we must focus on students. The study concluded that teachers need to reflect on their practice in order to apply these ideas to their work and that constructivist teachers encourage students to constantly assess how the activity is helping them gain understanding.

\section{Keywords: Constructivism, Curriculum, Approach, Reflect}

The profile of learners has changed. They are digital natives "marching through our schools, carrying a transformational change in their pockets in the form of powerful multimedia handheld devices” (Chen, 2010, pp. 213). The $21^{\text {st }}$ century, according to Pink (2005), will be dominated by a different way of knowing, being, and doing, and right-brain capacities will come increasingly to the fore. Such dispositions demand curricular change. Curriculum should not only focus on the tools necessary to develop reasoned and logical construction of new knowledge in our various fields of study, but also should progressively cultivate a culture that nurtures creativity in all our learners” (pp. 17). To meet 21st century expectations, educators therefore need to depart from the ideas and pedagogies of yesterday

\footnotetext{
${ }^{1}$ Physics, MANUU College of Teacher Education: A Constituent College of Maulana Azad National Urdu University, Hyderabad, India

*Responding Author

(C) 2017 Alam M; licensee IJIP. This is an Open Access Research distributed under the terms of the Creative Commons Attribution License (www.creativecommons.org/licenses/by/2.0), which permits unrestricted use, distribution, and reproduction in any Medium, provided the original work is properly cited.
} 


\section{Constructivism and the Classroom Curriculum}

and become bold advocates to develop the sorts of learning dispositions needed for our learners and their work futures.

Dewey (1938) emphasized the role of the student in the educational process and the role of the teacher in guiding the student through a rigorous academic routine that matches both the individual inclination and ability of the child. He suggested that experience is "educative" when useful knowledge develops through cooperative inquiry in an authentic context within a community of practice (pp. 138). The notion that learning involves students as co-creators and collaborative problem-solvers is indeed an important one, and teachers and schools that work to capitalize on the generational characteristics of sharing, researching, evaluating, and collaborating with peers, are more likely to enact and inspire teaching and learning practices that emulate the forms of sharing and social engagement that are flourishing in the 21st century world. In the spirit of student-centered accountability, a 21st century education must thus be tied to outcomes and proficiency in both core subject knowledge and 21st century skills that are expected and highly valued in and beyond school. In other words, rigorous academic standards should drive learning and provide the context for learning 21st century skills. Zhao (2009) outlines five core assumptions which can be used to guide decisions about what schools should consider in their curricula:

1. Skills and knowledge that are not available at a cheaper price in other countries or that cannot be rendered useless by machines;

2. Creativity, interpreted as both ability and passion to make new things and adapt to new situations;

3. New skills and knowledge that are needed for living in the global world and the virtual world (examples include foreign languages, global awareness, and multicultural literacy, and knowledge to cope with the global world, and digital or technology literacy for the virtual world);

4. High-level cognitive skills such as problem solving and critical thinking;

5. Emotional intelligence - the ability and capacity to understand and manage emotions of self and others, the ability to interact with others, understand others, communicate with others, and manage one's own feelings (pp. 150-151)

Lieberman (1995) emphasized that this new paradigm of professional development calls for ongoing study and problem solving among teachers in the service of a dual agenda: promoting more powerful student learning and transforming schools. These teachers engaged their students in reflective processes. They (i) developed reflective attitudes in their students (ii) explicitly taught metacognitive skills and processes (iii) made space for reflection in the classroom and (iv) used and encouraged a responsive interaction style. Dewey (1933) identified three attitudes as prerequisites for reflective teaching:

- $\quad$ Open-mindedness: an 'active desire to listen to more sides than one'

- $\quad$ Responsibility: an ability to ask 'why am I doing what I am doing in the classroom?'

- Wholeheartedness: an ability to take risks and act. 
Students adopting a deep approach to learning characteristically exhibit: an explicit intent to develop their own understanding of material (Biggs, 2003; Entwistle, 1990); knowledge which is highly structured (Biggs \& Collis, 1982; Boulton-Lewis, 1998); an ability to apply their own and other's ideas/concepts to new situations (Ramsden, 2003), and; a highly developed integration of knowledge (Biggs, 2003). These qualities manifest themselves in student performance as:

1. Enhanced understanding (Bodner, 1986),

2. $\quad$ Enhanced comprehension (Leonard \& Penick, 2000; Von Glasserfield, 1987).

3. More spontaneous venturing of ideas (Chin \& Brown, 2000);

4. More elaborate explanations that describe mechanisms and cause-effect relationships (Entwistle \& Hounsell, 1975) or refer to personal experiences (Brookfield, 1985);

5. Questions that focus on explanations and causes, predictions, or resolving discrepancies in knowledge and engaging in theorizing (Chin \& Brown, 2000);

6. Constructing more elaborate, well-differentiated knowledge structures (Pearsall, Skipper, \& Mintes, 1997).

Therefore, to maximise the quality of student learning outcomes we must construct learning environments that ensure students' adaptive responses to our curriculum are congruent with our aims (Biggs, 2003; Boud, 1982; Ramsden, 2003), something which Biggs (2003) calls "backwash." Through constructively aligning desired learning outcomes with assessment tasks (Biggs, 2003), it is possible to remove incentives for reproduction of material (what we call "negative backwash", or a surface approach) while providing students with the opportunity to demonstrate deeper engagement with their learning ("positive backwash"). Constructivist assumes that learners construct their own knowledge on the basis of interaction with their environment. Four epistemological assumptions are at the heart of what we refer to as "constructivist learning."

1. Knowledge is physically constructed by learners who are involved in active learning.

2. Knowledge is symbolically constructed by learners who are making their own representations of action;

3. Knowledge is socially constructed by learners who convey their meaning making to others;

4. Knowledge is theoretically constructed by learners who try to explain things they don't completely understand.

The "Constructive Learning Design" emphasizes these six important elements:

1. Situation,

2. Groupings,

3. Bridge,

4. Questions,

5. Exhibit, and

6. Reflections. 
These elements are designed to provoke teacher planning and reflection about the process of student learning. Teachers develop the situation for students to explain, select a process for groupings of materials and students, build a bridge between what students already know and what they want them to learn, anticipate questions to ask and answer without giving away an explanation, encourage students to exhibit a record of their thinking by sharing it with others, and solicit students' reflections about their learning. These six elements integrate and work as a whole. According to Piaget's (1970) cognitive development theory, peer interaction is a source of experience that evokes cognitive conflict (disequilibrium) in children, and human beings all have a tendency to reduce this conflict and re-establish an equilibrium at a higher level. For Vygotsky (1978), the cognitive development begins with an interaction (Liang \& Gabel). Based on Vygotsky's theory, one important step in designing

- Instruction to develop complex mental functions is the analysis of the

- Z Zone of proximal development — the distance between the actual

- Developmental level that is reflected in the child‘s independent problem-solving

- $\quad$ Process and the problem-solving level that is accomplished with guidance.

- $\quad$ Most importantly, the zone of proximal development is

- $\quad$ Created in the interaction between students and the instructor or in the

- $\quad$ Operative problem-solving with peers (Liang\& Gabel).

Cooperative learning is the educative use of small student groups so that student's work together to increase classroom learning. It is said that cooperative learning has positive impacts on —achievement, higher-level reasoning skills, motivation, attitudes, self-esteem, collaborative skills, and other important educational outcomes in the affective domainll. For making teaching process effective, it is suggested that the students should be organized into cooperative groups to build an effective learning group (Liang\& Gabel).

\section{CONSTRUCTIVIST CURRICULUM DEVELOPMENT}

The curriculum is the heart of education, the sharing of learning experiences between the teacher and learner. All else in the system should be derived from this: how learners should be assessed, how teachers should be trained and develop, what textbooks and other learning support materials should be like, how schools and the educational system should be organized and managed, and the allocation of resources necessary for the system to function. According to Jonassen (1991), there are three major phases of curriculum development of analysis, design, and evaluation.

\section{Content analysis}

One of the components of the first phase is content analysis. Content areas do not have strict boundaries since relevancy can be found in multiple disciplines. The teacher can define a major content domain but she cannot limit its scope with arbitrary boundaries. Strommen (1992) states that context and content are crucial in a constructivist approach and they determine the method and strategies employed in a course. Learning is situated in rich contexts and knowledge gained from a given domain has particular relevance to that domain. Therefore, the goal of constructivist educators is to guide students to think and act like 


\section{Constructivism and the Classroom Curriculum}

experts. Constructivists are also interested in the learner's prior knowledge. However, the emphasis is not on the learner's prior knowledge but on his cognitive processes, self-reflective skills, and the learning process itself. The goal is to cultivate the learners' thinking and knowledge construction skills.

\section{Design}

According to Wilson (1997), in a constructivist design, learners and teachers participate in the design process as characteristic of design. Moreover, the design process has a complex, non-linear structure that sometimes can lead to chaos around big ideas with multi-goals. Active learning method is the key principle of constructivist design, in which learners construct knowledge by means of physical and mental activities and actively engaging with learning activities. These activities might be things like problem solving, doing projects, having real-life experiences, story-writing, developing newspapers, searching, researching, doing experiments, developing puzzles, playing games, as well as story-telling, role playing, skepticism, analysis, synthesis (Strommen, 1992). Constructivist curriculum also focuses on the sharing of individual meaning; and the knowledge constructed by cooperation with peers (Driver \& Oldham, 1986). Thus, another important method used in a constructivist design is a collaborative learning. The common point of this method is that group members are responsible for both their learning and the learning of group members; the success of the group is rewarded. Other activities are applied in a constructivist design that encourage making sense of the subject matter, exposure to multiple sources of information, and opportunities for students to demonstrate their understanding in diverse ways, such as problem-based learning, inquiry activities, dialogues with peers and teachers.

\section{Evaluation}

According to Driver\& Oldham (1986), one of the important duties of teachers in a constructivist is to assess the students learning. Outcomes of constructivist activities are unique and varied, and learning is a reflection of assessment. Thus, learners play an active, effective and critical role in assessment, as well as realize the meaning of what they have experienced via an assessment process. The authentic assessment approach is suitable for constructivist development. In this framework, learning and assessment processes should link together. Thus, learners continue to learning throughout the assessment process. Authentic assessment includes peer-assessment and self-assessment. In self-assessment processes, learners evaluate their own personal development levels of learning according to the criteria they determine with their teachers. Another important aspect of evaluation in constructivist approaches is the idea of negotiation. When students negotiate among themselves and with the teacher issues relating to content, objectives, expectations, and evaluation components, they are more likely to embrace them and be responsible for accomplishing the tasks. Constructivist teachers allow learners to have an active role in the evaluation process (Jonassen, 1992). Allowing learners to evaluate their own work, provides them the opportunity to gain ownership of the evaluation process, thus making them accountable for their own learning. In addition, evaluation of one's own work promotes self-reflexive processes, which is another goal of constructivist learning. 


\section{CONSTRUCTIVE TEACHING METHODS/ STRATEGIES}

Constructivist teachers use methods in which students are encouraged to discover principles for themselves. The main goal of using constructivist teaching is that students learn how to learn by giving them to training to take initiative for their learning experiences. Constructivist teachers facilitate a process of learning in which students are encouraged to de responsible for their learning (J. L. Bencze, 2005). Teacher encourages direct student intellectual involvement through:

1. Small group work

2. Student presentation

3. Debate

4. Simulations

5. Brain-storming

6. Individual study

In the constructivist classroom, there is a great focus and emphasis on social and communication skills, as well as collaboration and exchange of ideas. Some activities encouraged in constructivist classrooms are:

1. Experimentation: Students individually perform an experiment and then come together as a class to discuss the results.

2. Research projects: Students research a topic and can present their findings to the class.

3. Field trips: This allows students to put the concepts and ideas discussed in class in a real-world context. Field trips would often be followed by class discussions.

4. Films: These provide visual context and thus bring another sense into the learning experience.

5. Class discussions: This technique is used in all of the methods described above. It is one of the most important distinctions of constructivist teaching methods. ${ }^{[2]}$

\section{CLASSROOM CURRICULUM THAT REFLECT CONSTRUCTIVISM}

In the constructivist classroom, students work primarily in groups and learning and knowledge are interactive and dynamic. There is a great focus and emphasis on social and communication skills, as well as collaboration and exchange of ideas. Constructivist approaches can also be used in online learning. For example, tools such as discussion forums, wikis and blogs can enable learners to actively construct knowledge. Because existing knowledge schemata are explicitly acknowledged as a starting point for new learning, constructivist approaches tend to validate individual and cultural differences and diversity. Translating theory into constructivist-based practices can be guided by a number of key design principles. Murphy (1997a) summarizes Jonassen’s (1994, p. 35) eight principles for guiding instructional design as follows:

1. Provide multiple representations of reality.

2. Represent the natural complexity of the real world.

3. Focus on knowledge construction, not reproduction.

4. Present authentic tasks (contextualizing rather than abstracting instruction).

(C) The International Journal of Indian Psychology, ISSN 2348-5396 (e)| ISSN: 2349-3429 (p) | 25 
5. Provide real-world, case-based learning environments, rather than predetermined instructional sequences.

6. $\quad$ Foster reflective practice.

7. Enable context- and content-dependent knowledge construction.

8. Support collaborative construction of knowledge through social negotiation

With these guidelines in mind, the following activities are offered to reflect instructional materials that are process oriented, problem based, contextual, interdisciplinary, and metacognitive in nature. They provide examples of ways teachers can incorporate constructivist practices of teaching and learning into their instruction, curriculum, and assessment practices.

\section{Curriculum Practices}

- $\quad$ Applied learning designs

- Interdisciplinary integration

- $\quad$ Field-related experiences

- $\quad$ School-community linkages

\section{Instructional Practices}

- $\quad$ Experiential learning

- $\quad$ Problem-based learning

- $\quad$ Student-directed learning

- $\quad$ Mentoring

\section{Assessment Practices}

- $\quad$ 9. Journal writing

- 10 . The scoring rubric

- 11. Portfolios

- $\quad$ 12. Observation checklists

\section{THE ROLE OF TEACHER IN CONSTRUCTIVIST CLASSROOM}

The teacher's role in a constructivist classroom is to prompt, facilitate and act as an expert learner who can guide students into adopting cognitive strategies such as self testing, articulating understanding, asking probing questions, and reflection. The teacher in constructivist classrooms organize information around big ideas that engage the students' in developing new insights, and to connect them with their previous learning. The activities are student-centered, and students are encouraged to ask their own questions, carry out their own experiments, make their own analogies, and come to their own conclusions. Thus, the teacher's main focus should be on guiding students by asking questions that will lead them to develop their own conclusions on the subject. It "requires a paradigm shift," as well as "the willing abandonment of familiar perspectives and practices and the adoption of new ones" (Brooks and Brooks, p. 25).David Jonassen identified three major roles for facilitators to support students in constructivist learning environments: 
$\begin{array}{ll}- & \text { Modeling } \\ \text { - } & \text { Coaching } \\ \text { - } & \text { Scaffolding }\end{array}$

\section{IMPLICATIONS OF CONSTRUCTIVIST CURRICULUM}

Central to the tenet of constructivism is that learning is an active process. Information may be imposed, but understanding cannot be, for it must come from within. Constructivism requires a teacher to act as a facilitator whose main function is to help students become active participants in their learning and make meaningful connections between prior knowledge, new knowledge, and the processes involved in learning. Brooks and Brooks (1993) summarize a large segment of the literature on descriptions of "constructivist teachers". They conceive of a constructivist teacher as someone who will:

- $\quad$ encourage and accept student autonomy and initiative;

- $\quad$ use a wide variety of materials, including raw data, primary sources, and interactive materials and encourage students to use them;

- $\quad$ inquire about students' understandings of concepts before sharing his/her own understanding of those concepts;

- $\quad$ encourage students to engage in dialogue with the teacher and with one another;

- $\quad$ encourage student inquiry by asking thoughtful, open-ended questions and encourage students to ask questions to each other and seek elaboration of students ${ }^{\text {ee }}$ initial responses;

- $\quad$ engage students in experiences that show contradictions to initial understandings and then encourage discussion;

- $\quad$ provide time for students to construct relationships and create metaphors;

- assess students' understanding through application and performance of openstructured tasks;

Hence, from a constructivist perspective, the primary responsibility of the teacher is to create and maintain a collaborative problem-solving environment, where students are allowed to construct their own knowledge, and the teacher acts as a facilitator and guide.

\section{CONCLUSION}

Constructivism hypothesizes that individuals will try to make sense of all information that they perceive, and that each individual will, therefore, "construct" their own meaning from that information. It promotes learning through experience in an environment that involves the "real world" and offers meaningful, personally interesting challenges. Moreover it requires active learning, provides opportunities to solve real world problems, answer real questions, address real needs and offers the student an opportunity to perform as an expert or professional in their chosen field. Approaching instruction from the constructivist continuum reaches a broader range of students and increases comprehension and self-confidence in all students, teaching students to think for themselves, ask questions and seek answers. The constructivist focus on the social context and larger community of learners has resulted in a major shift away from individually-based instruction to instruction that incorporates and embeds teaching within the larger community of peers, younger students, as well as those

(C) The International Journal of Indian Psychology, ISSN 2348-5396 (e)| ISSN: 2349-3429 (p) | 27 
who are older. This legacy of constructivism will likely prove to be a lasting and meaningful shift in the structure of schooling. If our efforts in reforming education for all students are to succeed, then we must focus on students. The principles of constructivism, increasingly influential in the organization of classrooms and curricula in schools, can be applied to teaching and learning. Teachers need to reflect on their practice in order to apply these ideas to their work. Constructivist teachers encourage students to constantly assess how the activity is helping them gain understanding. By questioning themselves and their strategies, students in the constructivist classroom ideally become "expert learners." This gives them everbroadening tools to keep learning. With a well-planned classroom environment, the students learn HOW TO LEARN. Thus, as success follows success, positive changes in the teaching are facilitated by a credible mentor, who provide the stimulus and support in curriculum implementation.

\section{Acknowledgments}

The author appreciates all those who participated in the study and helped to facilitate the research process.

Conflict of Interests: The author declared no conflict of interests.

\section{REFERENCES}

Biggs, J. B. (2003), “Teaching for Quality Learning at University (2nd ed.)”, Maidenhead: Open University Press.

Biggs, J. B. and Collis, K. F. (1982), "Evaluating the Quality of Learning, The SOLO Taxonomy (Structure of the Observed Learning Outcome)”, New York \& London: Academic Press.

Bodner, G. M. (1986), “Constructivism: a Theory of Knowledge”, Journal of Chemical Education, 63, 873-878.

Boud, D. (1982), “Towards Student Responsibility for Learning', In D. Boud (Ed.), Developing Student Autonomy in Learning. London: Kogan Page.

Boulton-Lewis, G. M. (1998), “Applying the SOLO Taxonomy to Learning in Higher Education”, In B. Dart \& G. M. Boulton-Lewis (Eds.), Teaching and Learning in Higher Education. Victoria: Australian Council for Educational Research.

Brookfield, S. D. (1985), "Developing Critical Thinkers: Challenging Adults to Explore Alternative Ways of Thinking and Acting”, San Francisco: Jossey Bass.

Brooks, G. and Brooks, M. (1999), "In Search of Understanding: The Case for Constructivist Classrooms”, Alexandria, VA: Association for Supervision and Curriculum Development.

Brooks, J.G. and Brooks, M.G. (1993), "In Search of Understanding: the Case for Constructivist Classrooms”, Alexandria, VA: American Society for Curriculum Development.

Chen, M. (2010), “Education Nation: Six Leading Edges of Innovation in our Schools”, San Francisco, CA: Jossey Bass. 
Chin, C. and Brown, D. E. (2000), "Learning Deeply in Science: An Analysis and Reintegration of Deep Approaches in Two Case Studies of Grade 8 Students”, Research in Science Education, 30(2), 173-197.

Dewey, J. (1933), “How We Think”, Buffalow, NY: Prometheus Books. (Original works published in 1910).

Dewey, J. (1938), “Experience and Education”, New York: Collier Books, 25-50.

Driver, R. and Oldham, V. (1986), “A Constructivist Approach to Curriculum Development in Science”, Studies in Science Education, 13, 105- 122.

Entwistle, N. J. (1990), “The Use of Research on Student Learning in Quality Assessment”, In G. Gibbs (Ed.), Improving Student Learning, through Assessment and Evaluation, Oxford: The Oxford Centre for Staff Development.

Entwistle, N. J. and Hounsell, D. (1975), “How Students Learn”, Lancaster: Institute for Research and Development in Post-compulsory Education, University of Lancaster.

Jonassen, D. H. (1992), "Evaluating Constructivistic Learning”, In T. M. Duffy \& D.H. Jonassen (Eds.), Constructivism and the Technology of Instruction, Hillsdale, NJ: Lawrence Erlbaum Associates Inc, 137-148.

Jonassen, D.H. (1991), “Objectivism versus Constructivism: Do We Need a New Philosophical Paradigm?” Journal of Education Research, 39 (3), 5-14.

Leonard, W. H. and Penick, J. E. (2000), “How do College Students Best Learn Science?”, Journal of College Science Teaching, 5, 385-388.

Lieberman, A. (1995), "Practices that Support Teacher Development”, Phi Delta Kappan.

Murphy, E. (1997a), “ Constructivism from Philosophy to Practice”, Retrieved http://www.stemnet.nf.ca/ elmurphy/emurphy/cle.html

Pink, D. H. (2005), “A Whole New Mind: Why Right Brainers will Rule the Future”, New York: Riverhead.

Ramsden, P. (2003), “Learning to Teach in Higher Education”, (2nd Edition), London and New York: Routledge Falmer.

Strommen, E. (1992), “Constructivism, Technology, and the Future of Classroom Learning”, Education \& Urban Society, 24(4), 466-478.

Von Glasserfield, E. (1987), “Learning as a Constructive Activity”, In C. Janvier (Ed.), Problems of Representation in the Teaching and Learning of Mathematics. New Jersey: Lawrence Erlbaum Associates.

Vygotsky, L. (1978), “Mind in Society”, Cambridge, MA: Harvard University Press.

Wilson, B. (1996), “Introduction: What is a Constructivist Learning Environment?”, In B. Wilson (Ed.), Constructivist Learning Environments, Englewood Cliffs, NJ: Educational Technology Publications, 24-48.

Zhao, Y. (2009), “Catching Up or Leading the Way”, Alexandria, VA: ASCD.

How to cite this article: Alam M (2017). Constructivism and the Classroom Curriculum. International Journal of Indian Psychology, Vol. 5, (1), DIP: 18.01.103/20170501, DOI: $10.25215 / 0501.103$ 